\title{
PERANAN SEKTOR PERTANIAN DI KABUPATEN MINAHASA TENGGARA
}

\author{
Geraldo G. Pondaag \\ Gene H.M. Kapantow, \\ Lorraine W.Th. Sondak
}

\begin{abstract}
This study aimed to assess the role of the agricultural sector in Southeast Minahasa Regency. The role was measured by the contribution of the agricultural sector in GRDP and the position of the agricultural sector in the regency economy, whether as it was a base or non-base sector. This research was conducted in Southeast Minahasa Regency. The data used were collected from the Central Bureau of Statistics, both South Minahasa and North Sulawesi offices, Planning Board (Bappeda) of Southeast Minahasa, and the Agricultural Agency of Southeast Minahasa Regency. The data were analyzed by calculating the contribution of the agricultural sector, $L Q$ and $D L Q$. The results showed that inspite of the drop in recent years, the agricultural sector remained had the largest contribution in GRDP of Southeast Minahasa Regency. Based on LQ analysis, it was shown that the agricultural sector was one of the four base sectors. Other base sectors were mining and quarrying, manufacturing, and construction sectors. Furthermore, from five sub-sectors within the agricultural sector, two of them were base sub sectors, namely food crops and plantation, while livestocks, forestry and fisheries were non-base sub-sectors. Based on DLQ analysis, the position of the agricultural sector in the future would remain as a base sector. There would be several sub-sectors in agriculture that had the potential to become base sub-sectors in the future, namely food crops, plantation, livestock and forestry, while fisheries subsector was predicated to remain as a non base sub-sector in the future.
\end{abstract}

Keywords: Contributions Agriculture, Sector Base, $L Q$ And DLQ

\begin{abstract}
ABSTRAK
Penelitian ini bertujuan untuk mengkaji peranan sektor pertanian di Kabupaten Minahasa Tenggara. Peranan tersebut diukur dari kontribusi sektor pertanian pada PDRB dan posisi sektor pertanian apakah merupakan sektor basis atau non basis. Penelitian ini dilakukan di Kabupaten Minahasa Tenggara. Data yang digunakan dikumpulkan dari Badan Pusat Statistik Minahasa Selatan, Badan Pusat Statistik Sulawesi Utara, BAPPEDA Minahasa Tenggara, dan Dinas Pertanian Minahasa Tenggara. Data kemudian dianalisis dengan menghitung kontribusi sektor pertanian, LQ dan DLQ. Hasil Penelitian menunjukan bahwa walaupun terjadi penurunan dalam beberapa tahun terakhir ini, namun sektor pertanian tetap masih merupakan sektor yang memiliki kontribusi terbesar dalam PDRB Kabupaten Minahasa Tenggara. Hasil perhitungan LQ menunjukan bahwa sektor pertanian merupakan satu di antara empat sektor basis. Sektor basis lainnya adalah sektor pertambangan dan penggalian, sektor industri pengolahan, serta sektor bangunan. Selanjutnya dari lima subsektor pertanian subsektor tanaman bahan makanan, dan subsektor tanaman perkebunan merupakan subsektor basis. Sedangkan subsektor peternakan dan hasil-hasilnya, kehutanan serta sub sektor perikanan merupakan subsektor non basis. Berdasarkan perhitungan DLQ, di masa depan sektor pertanian diprediksi tetap akan menjadi sektor basis. Selanjutnya dari subsektor-subsektor pertanian, ada beberapa subsektor yang berpotensi untuk menjadi basis di masa yang akan datang, yaitu subsektor tanaman bahan makanan, subsektor tanaman perkebunan, subsektor peternakan dan hasil-hasilnya, serta subsektor kehutanan. Sedangkan subsektor perikanan belum dapat diharapkan menjadi basis di masa yang akan datang.
\end{abstract}

Kata kunci: Kontribusi Sektor Pertanian, Sektor Basis, LQ Dan DLQ 


\section{PENDAHULUAN}

\section{Latar Belakang}

Peranan suatu sektor dalam satu wilayah guna menunjang kegiatan ekonomi perlu diperhatikan dengan baik. Setiap wilayah memiliki sektor yang unggul dan berbedabeda.Pengembangan perekonomian dalam sektor pertanian berkaitan dengan situasi dan kondisi dari setiap wilayah, baik sumberdaya alam, kualitas sumberdaya manusia, serta kebijakan pemerintah lokal.

Todaro (2006) Mendefinisikan pembangunan ekonomi adalah suatu proses yang struktur ekonomi, perubahan sosial, mengurangi atau menghapuskan kemiskinan, mengurangi ketimpangan dan pengangguran dalam konteks pertumbuhan ekonomi. Setiap upaya pembangunan ekonomi daerah mempunyai tujuan utama untuk meningkatkan jumlah dan jenis peluang kerja untuk masyarakat daerah.Dalam upaya untuk mencapai tujuan tersebut pemerintah daerah dan masyarakatnya harus aktif mengoptimalkan sumber daya ekonomi yang tersedia untuk merencanakan dan membangun perekonomian daerah.

Dalam hal ini kemampuan Pemerintah daerah untuk melihat sektor yang memiliki keunggulan/kelemahan di wilayahnya semakin penting. Prospek yang lebih baik untuk di kembangkan dan di harapkan dapat mendorong sektor-sektor yang lain dapat berkembang.

Kabupaten Minahasa Tenggara merupakan kabupaten yang terbentuk dari hasil pemekaran Kabupaten Minahasa Selatan, Kabupaten Minahasa Tenggara memiliki potensi sumber daya alam sangat kaya. Berbagai hasil pertanian yang ada pun sangat menopang pertumbuhan ekonomi.Sektor pertanian di Kabupaten Minahasa Tenggara menjadi salah satu sektor yang berpotensi untuk pembangunan perekonomian wilayah.

\section{Manfaat Penelitan}

Sebagian besar penduduk yang ada di kabupaten Minahasa Tenggara bermata pencarian sebagai petani dan luas wilayah yang ada hampir sebagian besar lahan pertanian. Dalam rangka memberdayakan masyarakat pemerintah daerah dalam menghadapi tuntutan masyarakat yang semakin kompleks dan persaingan yang semakin tinggi maka dari itu perlu di kaji potensi apa saja yang di miliki oleh Kabupaten Minahasa Tenggara.

Berbagai macam hasil alam yang ada di Kabupaten ini menjadikan daya tarik tersendiri bagi setiap perencana wilayah dalam melihat keunggulan yang di miliki oleh kabupaten ini dengan potensi pertanian, sektor pertanian didukung oleh sub sektor tanaman bahan makanan, tanaman perkebunan, peternakan dan hasil-hasilnya, serta kehutanan dan perikanan. Menurut data PDRB tahun 2010-2013 menunjukan bahwa sektor pertanian memiliki PDRB yang tertinggi. Hal ini menunjukan bahwa sektor pertanian memiliki kontribusi terbesar dalam pembentukan PDRB Kabupaten Minahasa Tenggara.

\section{Rumusan Masalah}

Berdasarkan latar belakang yang sudah diuraikan maka yang menjadi masalah dalam penelitian ini adalah bagaimana peranan sektor pertanian dalam perekonomian Kabupaten Minahasa Tenggara.

\section{Tujuan Penelitian}

1. Mengkaji peranan sektor pertanian berupa kontribusi sektor pertanian di Kabupaten Minahasa Tenggara

2. Mengetahui apakah sektor pertanian merupakan sektor basis dalam perekonomian Kabupaten Minahasa Tenggara, baik untuk saat ini maupun pada masa yang akan datang.

Hasil dari penelitian ini diharapkan dapat memberi manfaat berupa bahan informasi 
bagi perencana wilayah tentang sektor basis khususnya sektor pertanian dan berapa besar dan danpaknya terhadap perekonomian Kabu- paten Minahasa Tenggara. Dan juga sebagai kajian dan masukan bagi penelitian selanjutnya.

Tabel 1. PDRB ADHK Kabupaten Minahasa Tenggara Menurut Lapangan Usaha Tahun 2010-2013

\begin{tabular}{|c|c|c|c|c|c|}
\hline No & Lapangan Usaha & 2010 & 2011 & 2012 & 2013 \\
\hline 1 & Pertanian & $317.456,45$ & $310.922,01$ & $324.386,07$ & $337.249,18$ \\
\hline 2 & $\begin{array}{l}\text { Pertambangan dan Peng- } \\
\text { galian }\end{array}$ & $89.049,40$ & $97.057,23$ & $102.844,40$ & $110.074,97$ \\
\hline 3 & Industri Pengolahan & $67,949,13$ & $73.065,70$ & $77.573,85$ & $83.725,46$ \\
\hline 4 & Listrik Gas \& Air Bersih & $5.856,19$ & $6.228,42$ & $6.672,86$ & $7.189,91$ \\
\hline 5 & $\begin{array}{l}\text { Bangunan } \\
\text { Perdagangan, Hotel Dan }\end{array}$ & $165.762,95$ & $183.549,32$ & $198,912,40$ & $215.979,08$ \\
\hline 6 & $\begin{array}{l}\text { Restoran } \\
\text { Pengangkutan \& Komu- }\end{array}$ & $74.617,96$ & $85.406,19$ & $93.719,62$ & $103.079,34$ \\
\hline 7 & nikasi & $56.582,33$ & $61.667,88$ & $66.077,15$ & $71.632,56$ \\
\hline 8 & $\begin{array}{l}\text { Lembaga Keuangan, Per- } \\
\text { sewahan, Jasa Perusahaan }\end{array}$ & $24.977,31$ & $26.837,76$ & $28.771,50$ & $30.557,51$ \\
\hline 9 & Jasa-Jasa & $82.049,97$ & $89.057,33$ & $94.867,93$ & $100.047,62$ \\
\hline & Total PDRB & $8.905,735,252,29$ & $933.791,84$ & $993.825,78$ & $1.059,535,63$ \\
\hline
\end{tabular}

Sumber BPS SULUT 2014a.

\section{TINJAUAN PUSTAKA}

\section{Pembangunan Ekonomi}

Pembangunan ekonomi di definisikan sebagai suatu proses yang menyebabkan pendapatan perkapita riil penduduk suatu masyarakat meningkat dalam jangka panjang (Sukirno, 1996). Berdasarkan definisi ini dapat di ketahui bahwa pembangunan ekonomi berarti adanya suatu proses pembangunan yang terjadi terus menerus yang bersifat menambah dan memperbaiki segala sesuatu menjadi lebih baik lagi.

Dalam pengembangan potensi ekonomi daerah tidak boleh di lupakan perlunya membangun yang sifatnya berkelanjutan. Pembangunan yang di laksanakan di daerah tidak boleh atau jangan sampai menguras sumber daya alam dan merusak lingkungan. Fungsi lingkungan dalam pembangunan harus tetap di pertahankan, lingkungan berfungsi sebagai sumber bahan baku untuk industri pengolahan, sebagai pengolah limbah alami, dan sebagai sumber kesenangan dan kenyamanan hidup. Dalam hal ini pemerintah daerah harus tetap bertindak sebagai pengawas dalam pembangunan, sehingga pembangunan yang terjadi di daerah tidak akan merusak sumber daya alam dan lingkungan (Suparmoko, 2002).

\section{Pembangunan Ekonomi Daerah}

Arsyat (2005) mendefinisikan pembangunan ekonomi daerah sebagai suatu proses di mana pemerintah daerah dan masyarakatnya mengelola sumber-sumber daya yang ada dan membentuk suatu pola 
kemitraan antara pemerintah daerah dan sektor swasta untuk menciptakan suatu lapangan kerja baru dan merangsang perkembangan kegiatan ekonomi dalam wilayah tersebut.

Setiap daerah mempunyai corak pertumbuhan ekonomi yang berbada dengan daerah lain. Oleh sebab itu, perencanaan pembangunan ekonomi suatu daerah pertamatama perlu menggali karakter ekonomi, sosial, dan fisik daerah itu sendiri, termasuk interaksinya dengan daerah lain. Dengan demikian, tidak ada strategi pembangunan ekonomi daerah yang dapat berlaku untuk semua daerah. Namun di pihak lain, dalam menyusun strategi pembangunan ekonomi daerah, baik jangka pendek maupun jangka panjang pemahaman mengenai teori pertumbuhan ekonomi wilayah, yang di rangkum dari kajian terhadap pola-pola pertumbuhan ekonomi daerah (Darwanto, 2006).

\section{Pengertian Produk Domestik Regional Bruto (PDRB)}

Informasi hasil pembangunan yang didapatkan dapat dimanfaatkan dalam penentuan kebijakan pembangunan suatu wilayah. PDRB merupakan ukuran keberhasilan pembangunan suatu wilayah, khususnya dibidang ekonomi salah satu alat yang dapat digunakan sebagai indikator pertumbuhan ekonomi di suatu wilayah.

Pendapatan regional didefinisikan sebagai tingkat (besarnya) pendapatan masyarakat pada wilayah, dimana tingkat pendapatan regional dapat diukur dari total pendapatan wilayah ataupun pendapatan rata-rata masyarakat pada daerah tersebut (Tarigan, 2007).

Produk Domestik Regional Bruto adalah jumlah nilai tambah bruto (gross value added) yang timbul dari seluruh sektor perekonomian di suatu wilayah dalam kurun waktu tertentu biasanya satu tahun ataupun dalam tiga bulan atau semesteran. Sedangkan, nilai tambah adalah nilai produksi (output) dikurangi dengan biaya antara (intermediate cost). Nilai tambah bruto mencakup komponen-komponen faktor pendapatan (upah dan gaji, bunga, sewa, dan keuntungan), penyusutan dan pajak tidak langsung neto. Jadi dengan menghitung nilai tambah bruto dari masing-masing sektor dan menjumlahkan nilai tambah bruto dari seluruh sektor tadi, akan menghasilkan Produk Domestik Regional Bruto atas dasar harga pasar (BPS SULUT, 2014b).

Manfaat dari data PDRB adalah sebagai berikut (BPS, 2014) :

1) Mengetahui atau menelaah struktur atau susunan perekonomian suatu wilayah.

2) Membandingkan perekonomian suatu wilayah dari waktu ke waktu.

3) Membandingkan perekonomian antar wilayah.

4) Merumuskan kebijaksanaan pemerintah. PDRB secara berkala dapat disajikan dalam dua bentuk yaitu atas dasar harga berlaku dan atas dasar harga konstan pada suatu tahun dasar maupun triwulan, sebagai berikut dijelaskan (BPS SULUT, 2014) :

1) Penyajian atas dasar harga berlaku, semua agregat pendapatan dinilai atas harga yang berlaku pada masing-masing tahun, baik pada saat menilai produksi dan biaya antara maupun pada penilaian komponen nilai tambah dan komponen pengeluaran PDRB.

2) Penyajian atas dasar harga konstan pada suatu tahun dasar, semua agregat pendapatan dinilai atas harga yang terjadi pada tahun dasar (dalam hal ini dipakai harga konstan didasarkan harga pada tahun 2000). Karena menggunakan harga tetap, maka perkembangan agregat dari tahun ke tahun semata-mata disebabkan oleh perkembangan riil dari kuantum produksi tanpa mengandung fluktuasi harga.

Dalam perhitungan PDRB atas dasar harga berlaku ada dua metode yaitu metode langsung dan metode tidak langsung.Metode 
langsung adalah perhitungan dengan menggunakan data daerah atau data asli yang menggambarkan kondisi daerah dan digali dari sumber data yang ada di daerah itu sendiri. Hal ini berbeda dengan metode tidak langsung adalah perhitungan dengan mengalokasikan pendapatan nasional menjadi pendapatan regional memakai berbagai macam indikator, antara lain jumlah produksi, jumlah penduduk, luas areal sebagai alokatornya (Tarigan, 2007).

Metode langsung dapat dilakukan dengan menggunakan tiga macam pendekatan (Tarigan, 2007) yaitu :

\section{1) Pendekatan Produksi}

Pendekatan produksi adalah penghitungan nilai tambah barang dan jasa yang diprediksi oleh suatu kegiatan/sektor ekonomi dengan cara mengurangkan biaya antara dari total nilai produksi bruto sektor atau subsektor tersebut. Pendekatan ini banyak digunakan untuk memperkirakan nilai tambah dari sektor/kegiatan yang produksinya berbentuk fisik/barang, misalnya pertanian, industri dan sebagainya. Nilai tambah merupakan selisih antara nilai produksi (output) dan nilai biaya antara (intermediate cost), yaitu bahan baku dari luar yang dipakai dalam proses produksi.

\section{2)}

Pendekatan Pendapatan

Dalam pendekatan pendapatan, nilai tambah dari setiap kegiatan ekonomi diperkirakan dengan menjumlahkan semua balas jasa yang diterima faktor produksi, yaitu upah dan gaji dan surplus usaha, penyusutan, dan pajak tidak langsung neto.

\section{3)}

Pendekatan Pengeluaran

Pendekatan dari segi pengeluaran adalah menjumlahkan nilai penggunaan akhir dari barang dan jasa yang diproduksi di dalam negeri. Jika dilihat dari segi penggunaan maka total penyediaan/produksi barang dan jasa itu digunakan untuk konsumsi rumah tangga, konsumsi lembaga swasta yang tidak mencari untung, konsumsi pemerintah, pembentukan modal tetap bruto (investasi), perubahan stok dan ekspor neto.

\section{Pertumbuhan Ekonomi}

Proses pertumbuhan ekonomi di pengaruhi oleh dua macam faktor, faktor ekonomi dan non-ekonomi. Pertumbuhan ekonomi suatu wilayah tergantung pada sumber daya alam, sumber daya manusia, modal, usaha, teknonologi, dan sebagainya, semua itu merupakan faktor ekonomi. Tetapi pertumbuhan ekonomi tidak mungkin terjadi selama lembaga sosial, kondisi politik dan nilai-nilai moral dalam suatu bangsa tidak menunjang. Didalam pertumbuhan ekonomi, lembaga sosial, sikap budaya, nilai moral, kondisi politik dan kelembagaan faktor non ekonomi (Jhingan, 1999).

Pertumbuhan ekonomi berarti perkembangan kegitan perekonomian yang menyababkan barang dan jasa di produksi dalam masyarakat bertambah dan kemakmuran masyarakat meningkat. Masalah pertumbuhan ekonomi dapat di pandang sebagai masalah makro ekonomi jangka panjang. Dari satu periode ke periode lainnya kemampuan suatu negara untuk menghasilkan barang dan jasa meningkat. Kemampuan yang meningkat ini di sebabkan dalam jumlah dan kulitasnya. Invstasi akan menambah jumlah barang modal. Disamping itu tenaga kerja bertambah sebagai akibat perkembangan penduduk, dan pengalaman kerja, dan pendidikan menambah keterampilan (Sukirno, 1996).

\section{Faktor-faktor Pertumbuhan Ekonomi}

Pendorong utama pertumbuhan ekonomi adalah bagaimana upaya penghematan peningkat jumlah modal atau sumber daya. Lebih lanjut bahwa pembangunan ekonomi bukanlah hanyah sekedar memiliki jumlah besar uang atau semata-mata fenomena ekonomi, akan tetapi 
mencakup semua aspek perilaku masyarakat untuk tumbuh dan berkembang dari kekuatan sendiri, menghilangkan ketidak sempurnaan pasar, perubahan struktur pembentukan modal, investasi yang tepat atau sosial budaya serta manajemen yang baik. (Jhingan, 1999).

\section{Teori Ekonomi Basis}

Teori Ekonomi Basis mendasarkan pandanganya bahwa laju pertumbuhan ekonomi suatu wilayah ditentukan oleh besarnya ekspor dari wilayah tersebut. Dalam pengertian ekonomi regional, ekspor adalah menjual produk/jasa ke luar wilayah baik ke wilayah lain di dalam negara itu maupun ke luar negeri. Pengertian ekspor termasuk tenaga kerja yang mendomisili di wilayah kita tetapi bekerja dan memperoleh uang dari wilayah lain. Demikian pula usaha-usaha lokal tetapi memiliki langganan dari luar wilayah dapat diketegorikan sebagai kegiatan basis. Pada dasarnya semua kegiatan baik penghasil produk maupun penyedia jasa yang mendatangkan uang dari luar wilayah karena kegiatannya adalah kegiatan basis. Lapangan kerja dan pendapatan disektor basis adalah fungsi dari permintaan yang bersifat exogenous (tidak tergantung pada kegiatan intern/permintaan lokal (Tarigan, 2002).

Perekonomian regional dapat dibagi menjadi dua sektor yaitu kegiatan- kegiatan basis dan kegiatan-kegiatan bukan basis :

a. Kegiatan-kegiatan basis adalahkegiatankegiatan yang mengekspor barangbarang atau jasa-jasa ke tempat keluar batas-batas perekonomian masyarakat yang bersangkutan atau yang memasarkan barang-barang/ jasa-jasa mereka pada orang-orang diluar perbatasan perekonomian masyarakat yang bersangkutan.

b. Kegiatan-kegiatan bukan basis adalah kegiatan-kegiatanmenyediakan barangbarang yang dibutuhkan oleh orangorang yang bertempat tinggal di dalam batas-batas perekonomian masyarakat yang bersangkutan. Kegiatan-kegiatan ini tidak mengekspor barang-barang, jadi luas lingkup produksi mereka dan daerah pasar mereka yang terutama adalah bersifat lokal (Glasson, 2000). Suatu cara untuk mengetahui apakah suatu sektor merupakan sektor basis atau non basis dapat digunakam beberapa metode, yaitu metode pengukuran langsung dan metode pengukuran tidak langsung (Budiharsono, 2005).

Logika dasar LQ adalah teori basis ekonomi yang intinya adalah karena industri basis menghasilkan barang-barang dan jasa di daerah maupun di luar daerah yang bersangkutan, maka penjualan ke luar daerah akan menghasilkan pendapatan bagi daerah tersebut. Selanjutnya, adanya arus pendapatan dari luar daerah ini menyebabkan terjadinya kenaikan konsumsi (consumption, c) dan investasi (investment, I) didaerah tersebut. Hal ini akan menaikan pendapatan dan menciptakan kesempatan kerja baru. Peningkatan pendapatan tersebut tidak hanya menaikan permintaan terhadap industri basis, tetapi juga menaikan permintaan akan industri non basis (lokal). Kenaikan permintaan (demand) ini akan mendorong kenaikan investasi pada industri yang bersangkutan dan juga industri lain (Widodo, 2006).

\section{METODOLOGI PENELITIAN}

\section{Waktu dan Lokasi Penelitian}

Penelitian ini dilaksanakan di Kabupaten Minahasa tenggara dan dari instansi-instansi terkait di Kab Minahasa Tenggara. Penelitian ini dimulai sejak bulan Februari-April 2015. 


\section{Jenis dan Sumber Data}

Data yang digunakan dalam penelitian ini merupakan data sekunder, antara lain :

a. PDRB ADHK Tahun 2000Kabupaten Minahasa Tenggara periode 2010-2013.

b. PDRB ADHK Tahun 2000 Provinsi Sulawesi Utara Tahun 2010-2013

\section{Konsepsi Pengukuran Variabel}

a. Nilai PDRB Provinsi Sulawesi Utara tahun 2010-2013 (Rupiah/Tahun) atas dasar harga konstan Tahun 2000.

b. Nilai PDRB Kabupaten Minahasa Tenggara tahun 2010-2013 (Rupiah/Tahun) atas dasar harga konstan Tahun 21000 .

c. PDRB sektor/sub sektor pertanian wilayah Kabupaten Minahasa Tenggara

d. PDRB total wilayah Kabupaten Minahasa Tenggara

e. PDRB sektor/sub sektor pertanian wilayah Provinsi Sulawesi Utara

Analisis Location Quotient (LQ) digunakan untuk mengidentifikasi sektor pertanian maupun sub sektor pertanian di kabupaten Minahasa Tenggara. Besarnya nilai LQ dapat diperoleh dari persamaan sebagai berikut :

$$
\mathrm{LQ}=\frac{v i / v t}{v i / v t}
$$

Keterangan :

LQ : Nilai Location Quotient

$\mathrm{Vi}$ : PDRB sektor/sub sektor pertanian wilayah kabupaten Minahsa Tenggara

vt : PDRB total wilayah kabupaten Minahasa Tenggara

Vi : PDRB sektor/sub sektor pertanian Wilayah Provinsi Sulawsesi Utara

Vt : PDRB total wilayah Provinsi Sulawesi Utara

Kriteria :

Apabila LQ > 1 berarti sektor maupun sub sektor pertanian merupakan sektor basis. Se- f. PDRB total wilayah Provinsi Sulawesi Utara

g. Rata-rata laju pertumbuhan sektor/sub sektor Kabupaten Minahasa Tenggara

h. Rata-rata laju pertumbuhan PDRB Kabupaten Minahasa Tenggara

i. Rata-rata laju pertumbuhan sektor/sub sektor Provinsi Sulawesi Utara

j. Rata-rata laju pertumbuhan PDRB seluruh sektor Provinsi Sulawesi Utara

\section{Metode Analisis Data}

1. Kontribusi sektor pertanian terhadap PDRB Kabupaten Minahasa Tenggara

Dalam penelitian ini di gunakan data

PDRB ADHK tahun 2000. Dengan rumus yaitu :

Kontribusi $=\frac{\text { Nilai } P D R B \text { sektor }-i}{\text { Total } P D R B} \times 100 \%$

\section{Analasis Posisi Sektor Pertanian}

\section{a. Kondisi Saat Ini}

dangkan $\mathrm{LQ} \leq$ berarti sektor maupun sub sektor pertanian merupakan sektor non basis.

b. Posisi di Masa Depan

Untuk mengatasi kelemahan metode LQ digunakam varians dari metode LQ yaitu Dynamic Location Quotient (DLQ). Metode DLQ menggambarkan posisi sektor maupun sub sektor pertanian di masa mendatang.

Dimana :

$$
\mathrm{DLQ}=\left\{\frac{(1+g i j) /(1+g j}{(1+G i) /(1+G j)}\right\}^{\mathrm{t}}
$$

DLQ : Indeks Dynamic Location Quotient

gij : Rata-rata laju pertumbuhan sektor/sub

sektor kabupaten Minahasa

Tenggara

gj : Rata-rata laju pertumbuhan PDRB

kabupaten Minahasa Tenggara

Gi : Rata-rata laju pertumbuhan sektor/sub sektor Provinsi Sulawesi utara

Gj : Rata-rata laju pertumbuhan PDRB seluruh sektor Provinsi Sulawesi

Utara

$\mathrm{t} \quad$ : Jumlah tahun analisis 
Untuk pertumbuhan sektor/sub sektor pertanian Kabupaten Minahasa Tenggara Tahun 2011- 2013 di hitung dengan rumus :

Laju Pertumbuhan $=\left\{\frac{\text { pertumbuhan tahun 2013-pertumbuhan tahun } 2012}{\text { pertumbuhan tahun } 2012} \times 100 \%\right\}$

Rata-rata laju pertumbuhan untuk tahun 2013 yaitu :

$\mathrm{gji}=\left\{\frac{\text { laju pertumbuhan } 2011+\text { la ju pertumbuhan } 2012+\text { laju pertumbuhan } 2013}{3} \times 100 \%\right\}$

Jika DLQ > 1, sektor maupun sub sektor pertanian masih dapat di harapkan untuk basis di masa yang akan datang. Jika DLQ $\leq 1$, sektor maupun sub sektor pertanian tidak dapat di harabkan untuk basis di masa yang akan datang (Suyatno, 2002).

c. Perbandingan Posisi Saat Ini dan di Masa Depan

Analisis gabungan LQ dan DLQ digunakan untuk mengetahui perubahan posisi dan potensi baik sektor maupun sub sektor untuk masa yang akan datang dengan rincain sebagai berikut :

LQ > 1 DAN DLQ > 1, berarti sektor pertanian tetap menjadi basis

$\mathrm{LQ}>1$ dan DLQ $\leq 1$, berarti sektor pertanian mengalami perubahan posisi dari basis menjadi non basis sehingga tidak dapat di harapkan menjadi basis di tahun-tahun yang akan datang

LQ $\leq 1$ dan DLQ $>1$, berarti sektor pertanian pada posisi non basis namun dapat diharapkan basis di tahun-tahun yang akan datang

$\mathrm{LQ} \leq 1$ dan $\mathrm{DLQ} \leq 1$, berarti sektor pertanian tetap non basis

\section{HASIL DAN PEMBAHASAN}

\section{Letak Geografis, Administratif dan kondisi Fisik}

Kabupaten Minahasa tenggara adalah salah satu kabupaten di provinsi sulawesi utara terletak pada 124'32'56''BT - 124'57'3''BT dan 0'50'28' 'LU - 1'7'17''LU.Ibu kota kabupaten Minahasa Tengggara adalah Ratahan, berjarak sekitar $75 \mathrm{~km}$ dari manado ibu kota Sulawesi Utara. Kabupaten Minahasa Tenggara secara administratif telah di tetapkan dengan UU No. 9 tahun 2007. Kabupaten Minahasa Tenggara merupakan kabupaten hasil pemekaran dari kabupaten Minahasa Selatan.

\section{Peranan Sektor Pertanian di Kabupaten Minahasa Tenggara}

Pertanian merupakan sala satu yang menjadi penggerak utama karena dengan melihat kemampuan yang mempunyai kemungkinan untuk dikembangkan dalam pertumbuhan pembangunan dan perekonomian kabupaten Minahasa Tenggara.Hal ini tergambar dalam Produk Domestik Regional Bruto Kabupaten. Minahasa Tengggara yang menunjukan bahwa nilai PDRB sektor pertanian mengalami peningkatan mulai dari tahun 2010-2013. Tabel5 menunjukan nilai produk domestik regional bruto atas dasar harga konstan 2000 (ADHK) tahun 2010-2013.

Berikut di tujukan dalam Tabel kontribusi sektor pertanian di Kabupaten Minahasa Tenggara. Kontribusi PDRB terbesar adalah sektor pertanian dengan nilai $35,90 \%$ di tahun 2010 , dan terjadi penurunan di tahun $201133,30 \%$, di tahun 2012 dengan nilai 32,64 \%, dan di tahun 2013 31,82\%. Selanjutnya akan di analisis posisi sektor pertanian. Kondisi saat ini analisis LQ digunakan untuk melihat posisi sektor pertanian dan sub sektornya 
apakah merupakan sektor basis atau non basis di Kabupaten Minahasa Tenggara. Tabel 6 menunjukan bahwa sektor pertanian masih merupakan satu di antara empat sektor basis. Sektor basis lainnya adalah sektor pertambangan dan penggalian, sektor industri pengolahan, dan sektor bangunan. Sektor non basis di Kabupaten Minahasa Tenggara adalah sekor listrik gas dan air bersih, sektor perdagangan dan restoran, sektor penganggkutan dan komunikasi, sektor keuangan dan jasa perusahaan, dan yang terakhir sektor jasajasa.

Tabel 5. PDRB Atas Dasar Harga Konstan (ADHK) Kabupaten Minahasa Tenggara tahun 2010-2013

\begin{tabular}{|c|c|c|c|c|}
\hline Lapangan Usaha & 2010 & 2011 & 2012 & 2013 \\
\hline 1. Pertanian & $317.456,45$ & $310.922,01$ & $324.386,07$ & $337.249,18$ \\
\hline $\begin{array}{l}\text { a. Tanaman Bahan } \\
\text { Makanan }\end{array}$ & $98.268,50$ & $169.124,55$ & $106.202,61$ & $109.760,40$ \\
\hline $\begin{array}{l}\text { b. Tanaman } \\
\text { Perkebunan }\end{array}$ & $177.181,31$ & $312.802,77$ & $170.081,40$ & $176.748,59$ \\
\hline c. Peternakan & $177.181,31$ & $40.894,88$ & $18.376,35$ & $19.346,62$ \\
\hline d. Kehutanan & $15.220,66$ & 899,99 & 916,55 & 936,52 \\
\hline e. Perikanan & 870,23 & $27.709,12$ & $28.809,17$ & $30.457,05$ \\
\hline $\begin{array}{l}\text { 2. Pertambangan dan } \\
\text { Penggalian }\end{array}$ & $89.049,40$ & $162.288,29$ & $102.844,40$ & $110.074,97$ \\
\hline 3. Industri Pengolahan & $67.949,13$ & $222.178,24$ & $77.753,85$ & $83.725,46$ \\
\hline $\begin{array}{l}\text { 4. Listrik, Gas dan Air } \\
\text { Bersih }\end{array}$ & $5.856,19$ & $12.372,07$ & $6.672,86$ & $7.189,91$ \\
\hline 5. Bangunan & $165.762,95$ & $183.549,32$ & $196.912,40$ & $215.976,08$ \\
\hline $\begin{array}{l}\text { 6. Perdagangan, Hotel } \\
\text { dan Restoran }\end{array}$ & $74.617,96$ & $83.406,19$ & $93.719,62$ & $103.079,34$ \\
\hline $\begin{array}{l}\text { 7. Pengangkutan dan } \\
\text { Komunikasi }\end{array}$ & $56.582,33$ & $61.667,88$ & $66.077,15$ & $71.632,56$ \\
\hline $\begin{array}{l}\text { 8. Keuangan, } \\
\text { Persewaan dan Jasa } \\
\text { Perusahaan }\end{array}$ & $24.977,31$ & $26.837,76$ & $28.771,50$ & $30.557,51$ \\
\hline 9. Jasa-Jasa & $82.049,97$ & $89.057,33$ & $94.867,93$ & $100.047,62$ \\
\hline Total PDRB & $884.301,70$ & $1.242 .713,85$ & $1.318 .211,86$ & $1.396784,81$ \\
\hline
\end{tabular}

Sumber : BPS Sulut 2014

Tabel 6. Sektor Basis Berdasarkan Nilai LQ Kabupaten Minahasa Tenggara Tahun 2010-2013.

\begin{tabular}{rccccc}
\hline Lapangan Usaha & \multicolumn{3}{c}{ LQ } & & Rata-Rata \\
& 2010 & 2011 & 2012 & 2013 & \\
& & & & & \\
\hline 1. Pertanian & 1,83 & 1,85 & 1,84 & 1,85 & 1,84
\end{tabular}




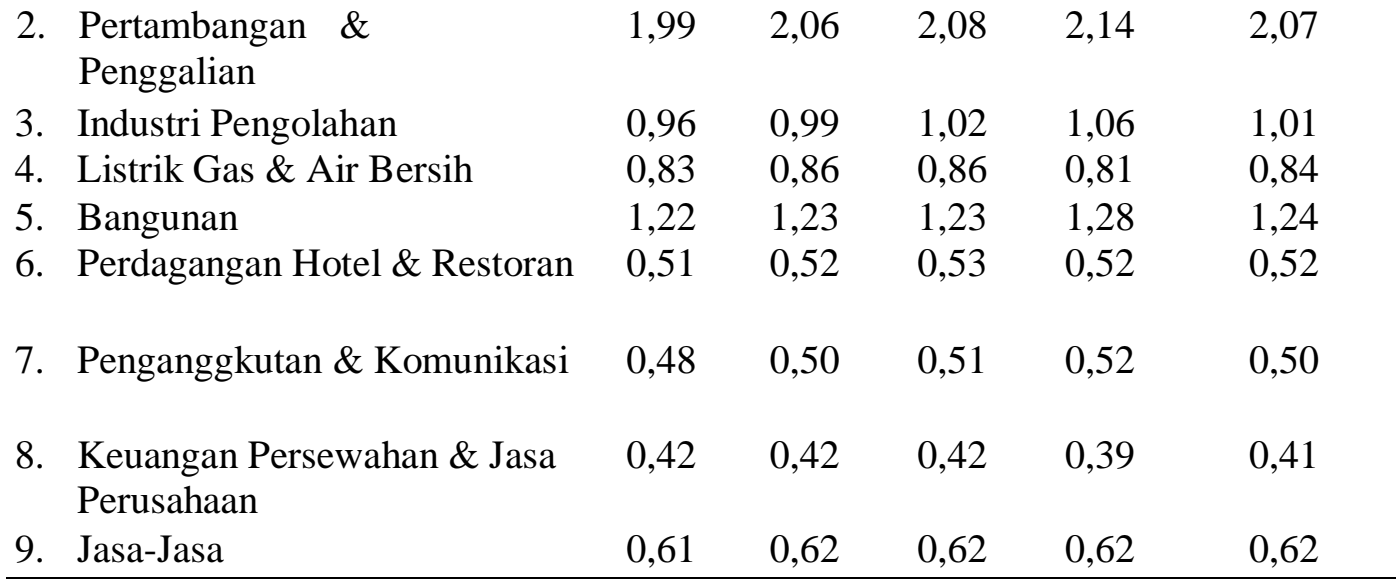

Sumber : Hasil Olahan 2015

Posisi di masa depan analisis DLQ digunakan untuk menggambarkan posisi sektor dan sub sektor pertanian di masa depan. Tabel 7 menunjukan bahwa di masa yang akan datang sektor pertanian tetap menjadi sektor basis. Jika dilihat dari sub sektor yang ada di Kabupaten Minahasa Tenggara ada beberapa sub sektor yang berpotensi untuk menjadi basis di masa yang akan datang yaitu sub sektor tanaman bahan makanan, sub sektor tanaman perkebunan, sub sektor peternakan dan hasil-hasilnya, serta sub sektor kehutanan. Sub sektor perikanan belum dapat diharapkan menjadi basis di masa yang akan datang sehingga tetap pada posisi non basis

Tabel 7. DLQ Sektor dan sub sektor pertanian di masa yang akan datang

\begin{tabular}{lc}
\hline Lapangan Usaha & DLQ \\
\hline 1. Pertanian & 1,01 \\
a. Tanaman Bahan Makanan & 1,03 \\
b. Tanaman Perkebunan & 1,01 \\
c. Peternakan \& Hasil-Hasilnya & 1,12 \\
d. Kehutanan & 1,09 \\
e. Perikanan & 0,90 \\
\hline
\end{tabular}

Sumber : Hasil Olahan 2015

Tabel. 8. Perubahan Posisi Sektor Berdasarkan Nilai LQ dan DLQ
Selanjutnya akan di analisis perbandingan kondisi saat ini dan di masa depan. Analisis LQ dan DLQ digunakan untuk mengetahui perubahan posisi dan potensi baik sektor maupun sub sektor pertanian di masa yang akan datang. Tabel 8 menunjukan posisi sektor dan sub sektornya. Sektor I sub sektor yaitu sektor pertanian dengan nilai DLQ 1,01 sehingga tetap pada posisi basis, sub sektor tanaman bahan makanan dengan nilai DLQ

1,03 tetap pada posisi basis, sub sektor tanaman perkebunan dengan nilai DLQ 1,01 tetap pada posisi basis, sub sektor peternakan dan hasilhasilnya dengan nilaii DLQ 1,12 dari non basis menjadi basis, sub sektor kehutanan dengan nilai DLQ 1,09 dari non basis menjadi basis, dan sub sektor perikanan dengan nilai DLQ 0,90 sehingga tetap pada posisi non basis. Sektor pertanian di kabupaten Minahasa Tenggara menjadi unggulan penggerak dalam perekonomian Kabupaten Minahasa Tenggara hal ini di sebabkan karena sektor pertanian mampu mendorong pertumbuhan dan produktifitas ekonomi sehingga kinerja perekonomian daerah akan semakin meningkat. 


\begin{tabular}{|c|c|c|c|}
\hline Lapangan Usaha & LQ & DLQ & Keterangan \\
\hline 1.Pertanian & 1,84 & 1,01 & $\begin{array}{l}\text { Basis- } \\
\text { Basis }\end{array}$ \\
\hline $\begin{array}{l}\text { a. Tanaman Bahan } \\
\text { Makanan }\end{array}$ & 1,96 & 1,03 & $\begin{array}{l}\text { Basis- } \\
\text { Basis }\end{array}$ \\
\hline $\begin{array}{l}\text { b. Tanaman } \\
\text { Perkebunan }\end{array}$ & 2,86 & 1,01 & $\begin{array}{l}\text { Basis- } \\
\text { Basis }\end{array}$ \\
\hline $\begin{array}{l}\text { c. Peternakan dan } \\
\text { Hasilnya }\end{array}$ & 0,92 & 1,12 & $\begin{array}{l}\text { Non Basis- } \\
\text { Basis }\end{array}$ \\
\hline d. Kehutanan & 0,39 & 1,09 & $\begin{array}{l}\text { Non Basis- } \\
\text { Basis }\end{array}$ \\
\hline e. Perikanan & 0,70 & 0,90 & $\begin{array}{c}\text { Non Basis- } \\
\text { Non Basis }\end{array}$ \\
\hline
\end{tabular}

Sumber : Hasil Olahan 2015

\section{KESIMPULAN DAN SARAN}

\section{Kesimpulan}

a. Sektor pertanian masih merupakan sektor dengan kontribusi terbesar dalam PDRB Kabupaten Minahasa Tenggara

b. Sektor pertanian merupakan salah satu sektor basis dalam perekonomian Kabupaten Minahasa Tenggara

c. Sub sektor tanaman bahan makanan dan sub sektor tanaman perkebunan adalah sub sektor dalam sektor pertanian yang merupakan sub sektor basis.

d. Di masa yang akan datang sektor pertanian akan tetap menjadi sektor.

e. Di masa yang akan datang sub sektor tanaman bahan makanan dan sub sektor tanaman perkebunan masih akan tetap menjadi sub sektor basis, di samping itu sub sektor peternakan dan hasil-hasilnya, serta sub sektor kehutanan juga akan berpotensi menjadi basis.

\section{Saran}

Berdasarkan penemuan dalam penelitian ini maka ada dua saran yang dapat diajukan yaitu:

1. Sebagai kontribusi terbesar pada PDRB Kabupaten Minahasa Tenggara dan juga sebagai sektor basis, maka sektor pertanian perlu untuk terus dikembangkan

2. Melihat potensi perikanan yang begitu besar di Kabupaten Minahasa Tenggara namun konribusinya pada PDRB masih relatif kecil dan bukan merupakan sektor basis, maka diperlukan kebijakan pemerintah untuk mendorong pengembangan sektor ini.

\section{DAFTAR PUSTAKA}

Arsyat, L. 2005. Ekonomi Pembangunan. Sekolah Tinggi Ilmu Ekonomi. YKPN. Yogyakarta.

BPS SULUT, 2014a .Minahasa Tenggara Dalam Angka. Badan Pusat Statistik Sulawesi Utara, Manado., 2014b.Produk Domestik Regional Bruto Provinsi Sulawesi Utara Menurut Lapangan Usaha. Badan Pusat Statistik Sulawesi Utara, Manado.

Budiharsono, 2005. Teknik Pembangunan Wilayah Pesisir dan Lautan.PT Pradnya Paramita. Jakarta.

Daniel, M. 2002. Pengantar Ekonomi Pertanian. Bumi Aksara. Jakarta.

Darwanto, 2006. Prinsip Dasar Pembangunan Ekonomi Daerah.

Glasson, 2000. Pengantar Perencanaan Regional Bagian Satu dan Dua(Terjemahan Paul Sitohang). Lembaga Penerbit Fakultas EkonomiUniversitas Indonesia. Jakarta. Jhingan, M, L. 1999. Ekonomi Pembangunan Dan Perencanaan, PT. RayaGrafindo Persada Jakarta. 
Kuncoro, M., 2004.Otonomi dan Pembangunan Daerah : Reformasi, Perencanaan, Strategi dan Peluang . Erlangga, Jakarta.

Laoh, E. 2008. Buku Ajar Ekonomi Pembangunan, Fakultas Pertanian Universitas Sam Ratulangi Manado.

Rita, H, 2010. Pengantar Ekonomi Pertanian. LP3S. Jakarta.
Riyadi dan Brathakusuma. Tahun 2005. Perencanaan Pembangunan Daerah. Gramedia Jakarta

Suhendra, E, S. 2004. Analisis Struktur Ekonomi Pertanian Indonesia, Model Input Output Jurnal Ekonomi dan Bisnis No 2, Jilid 9, Tahun 2004. Universitas Guna Darma Depok Sukirno, S. 1996. Pengantar Teori Makro Ekonomi, PT Raya Grafindo Persada, Jakarta. 